\title{
Towards an assessment of the balance state of the Greenland Ice Sheet
}

\author{
Carl E. Bøggild, Christoph Mayer, Steffen Podlech, Andrea Taurisano and Søren Nielsen
}

The climate of Europe is strongly influenced by heat transport by ocean currents flowing from equatorial regions towards the Arctic (Clark et al. 2002). During recent years, research has been increasingly focused on factors affecting this circulation, e.g. the freshwater budget of the Arctic which is influenced by glacial meltwater from North and East Greenland outlet glaciers (Linthout et al. 2000, Mayer et al. 2000). Furthermore, the climate is affected by snow cover that, apart from its contribution to the freshwater budget, provides feedback effects in that it reflects most of the solar radiation. Apart from Arctic sea-ice cover, the Greenland Ice Sheet is the largest permanent ice- and snow-covered area in the northern hemisphere, with an area of $1.67 \times 10^{6} \mathrm{~km}^{2}$ and by far the largest storage of ice with a volume of $2.93 \times 10^{6}$ $\mathrm{km}^{3}$ (Bamber et al. 2001). Most of the mass loss from the Greenland Ice Sheet (the least known mass-balance parameter) occurs in the marginal region of the ice sheet, which is also the area where the largest changes in albedo occur. The Geological Survey of Denmark and Greenland (GEUS) has for many years carried out research along the Greenland Ice Sheet margin to monitor changes of mass balance and melt conditions.

\section{Changes in mass balance: present knowledge}

Changes in mass balance over the interior part of the Greenland Ice Sheet can conveniently be assessed from snow pits and ice cores, because the 'history' is preserved as annual layers in the accumulation zone. At the ice margin this stratigraphic approach cannot be used due to melting of the surface. Monitoring of ablation is therefore carried out using stakes drilled into the ice. Until about 1980, mass balance measurements in Greenland were few and of short duration. During the 1980s, intensive studies were initiated, motivated mainly by hydropower investigations (Weidick 1995). This was followed by a period in the early and middle 1990s when climate-related mass-balance campaigns were carried out in North-East and North Greenland in conjunction with geological mapping expeditions (Bøggild et al. 1994; Thomsen et al. 1997). An overview of the various field activities is given in Fig. 1. An analysis of field results together with model estimates has yielded ablation rates varying from up to $10 \mathrm{~m} / \mathrm{yr}$

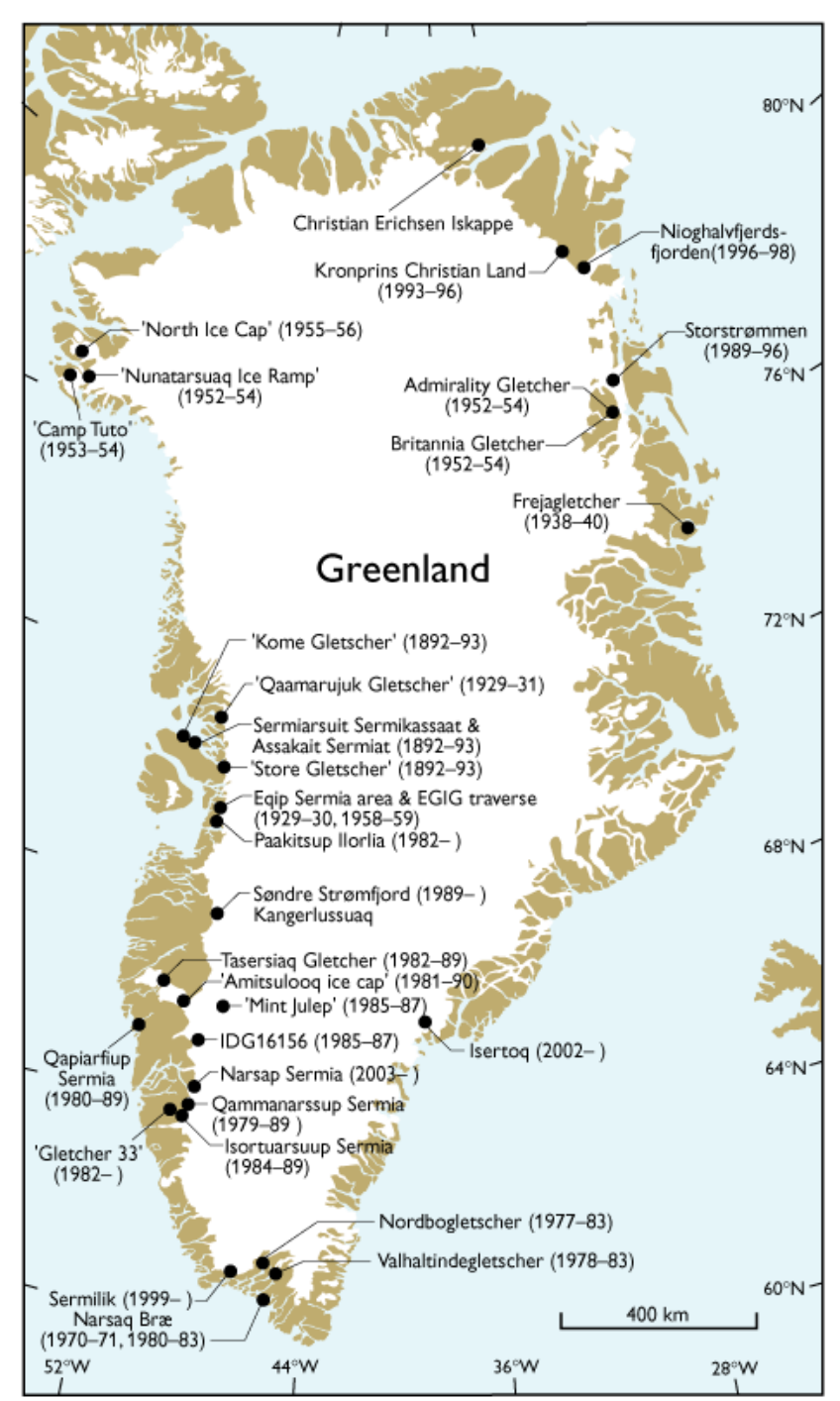

Fig. 1. Locations on the Greenland Ice Sheet margin where mass balance investigations have been carried out, including recent activities by the authors.

in the southernmost part of Greenland to a few metres per year in North-East Greenland (Huybrechts et al. 1991).

Since the traverse of the ice sheet during the Expédition Glaciologique Internationale au Groenland (E.G.I.G.) in 1957-1960, locations on this traverse route have been used for several investigations, including long-term surface-change and mass-balance studies (Finsterwalder 1959; Fischer et al. 


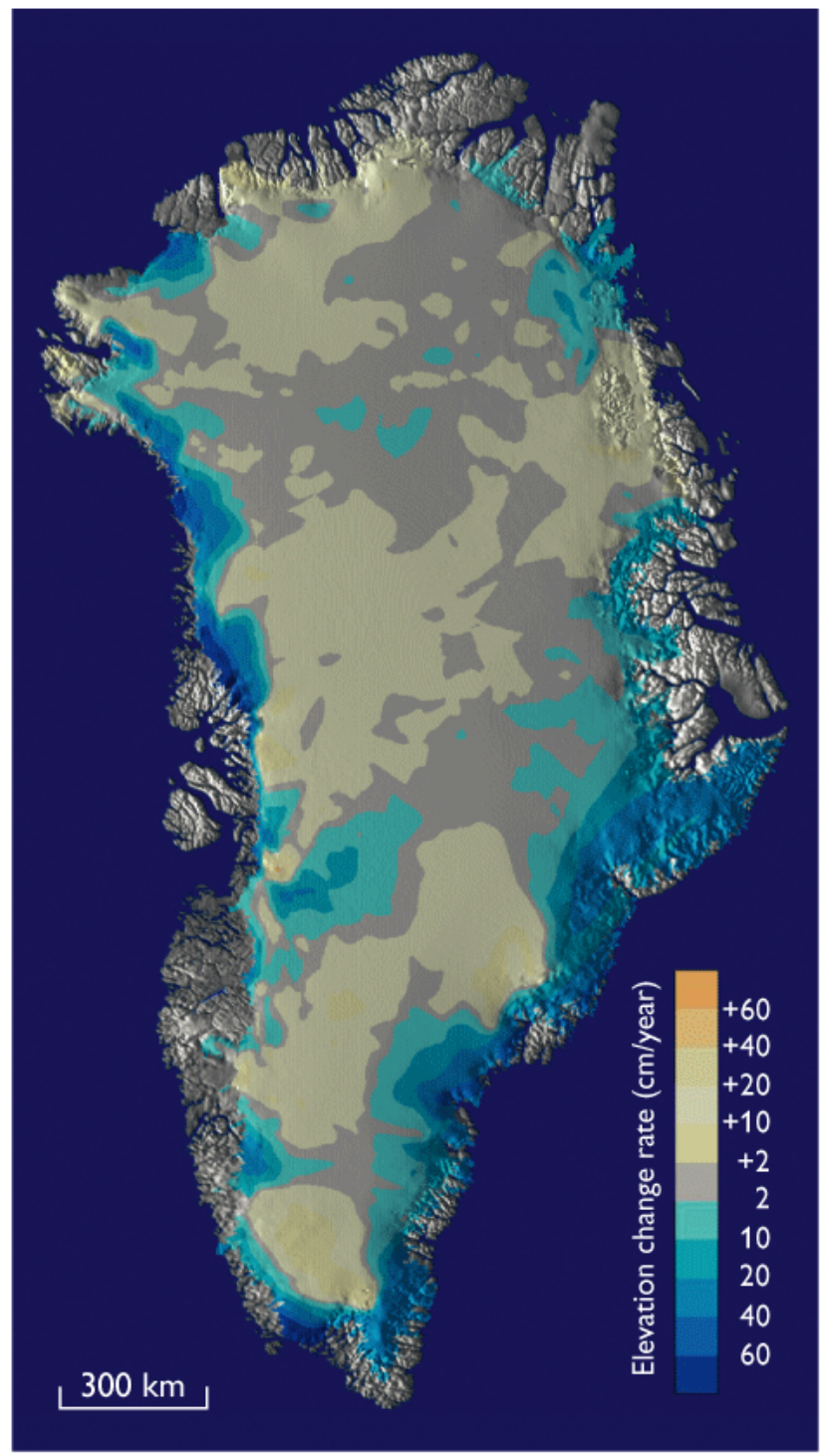

Fig. 2. Elevation changes in $\mathrm{cm} / \mathrm{yr}$ on the Greenland Ice Sheet from airborne laser altimetry detected during the PARCA campaign (ref.: http://aol.wff.nasa.gov/aoltm.html). Blue colour tones indicate areas of thinning.

1995). Major advances in the assessment of the Greenland Ice Sheet mass balance were achieved during the Program for Arctic Regional Climate Assessment (PARCA) between 1991 and 1999. The project was initiated with a balance assessment around the $2000 \mathrm{~m}$ altitude contour on the ice sheet, and was gradually expanded with add-on projects into a large-scale, multidisciplinary project to determine the balance state of the ice sheet (Thomas et al. 2001). These largescale investigations have incorporated both visible and radar satellite images, airborne radar depth sounding, multi-parameter core analysis, weather stations, climate-modelling etc. Most studies have been carried out in the interior parts of the ice sheet, where spatial variability of accumulation, ice thickness and other factors are small compared to the marginal regions. Hence, coverage over large areas can more easily be obtained from remote sensing data, combined with a few observations and ground-truth calibrations.

The PARCA campaign strongly improved the knowledge of snow accumulation distribution and provided a clear estimate of ice thickness and volume of the ice sheet. Although rather large spatial and temporal variability in local accumulation was demonstrated, the interior of the ice sheet as a whole was shown to be in approximate balance (Thomas et al. 2001). However, airborne laser altimetry extended observations further towards the ice margin and documented relatively rapid thinning particularly in the south to south-eastern and north-western parts of the ice sheet (Fig. 2; Krabill et al. 1999).

In the late 1990s, an analysis of elevation change history and mass balance was carried out by GEUS at two confined outlet glaciers, Sermilik Bræ in South Greenland and Qamanaarsuup Sermia in West Greenland (Figs 1, 3). Both studies confirm the observed thinning from laser altimetry by Krabill et al. (1999). The laser altimetry results are, however, restricted to the period from 1991 to 2001, whereas the GEUS elevation studies could be extended back to around 1950 using topographic models based on the earliest aerial photographs available. This longer time frame of the GEUS studies provides a more reliable estimate of the balance state, since the effects of year-to-year variability are reduced. Preliminary results show that the average thinning of the ice sheet margin over the last five decades may locally exceed the laser altimetry estimates of $1000 \mathrm{~mm} / \mathrm{yr}$ in the areas of investigation. The observed thinning at Sermilik Bræ ranges from 2000 to $8000 \mathrm{~mm} / \mathrm{yr}$, while at Qamanaarsuup Sermia thinning rates of around $1000 \mathrm{~mm} / \mathrm{yr}$ have been found. The thinning appears to be only in part due to increased melting at both sites.

\section{Towards automatic ablation observations}

The observed strong thinning of the Greenland Ice Sheet margin has called for the development of new automatic data collection methods. Traditionally, these measurements have been made with stakes drilled into the ice that were periodically visited to determine surface lowering by melting. However, the stakes need to be re-drilled at least once during the ablation season in order to secure a continuous time series. This is a highly labour-intensive and costly way to retrieve ablation data, particularly in view of the approximately $5000 \mathrm{~km}$ long perimeter of the ice sheet margin. To resolve this dilemma an automatic mass balance station (AMS) has been under development at GEUS since 2001 

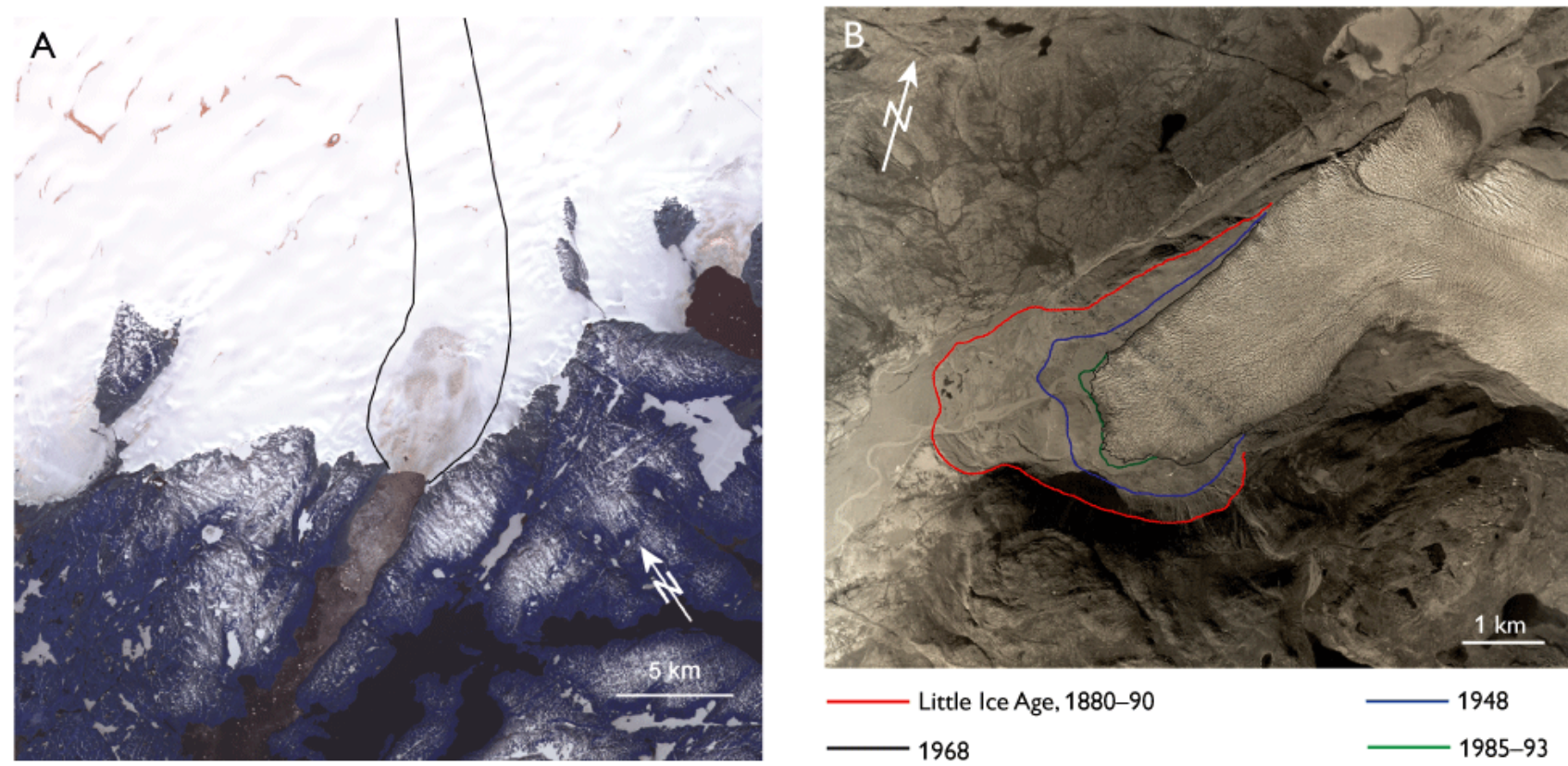

Fig. 3. Observed changes at Sermilik Bræ and Qamanaarsuup Sermia in historical time. A: Fjord and glacier front of Sermilik Bræ in 2001 recorded by ASTER imagery. The lateral margins of the drainage area are indicated by thin black lines. B: Terminus changes of Qamanaarsuup Sermia since the last advance during the Little Ice Age (1880-1890; Beschel 1961). The vertical aerial photograph was taken by the Danish Geodetic Institute in 1968 (reproduced by permission A.200/87).

(Mayer $e$ al. 2002), which, with a new concept of ablation measurements, will allow uninterrupted operation for several years. The most recent design combines a sturdy tripod with a specially developed sensor system that is coupled to an automatic, satellite-based data transmission system enabling data retrieval at six-hour intervals (Bøggild et al. in press).

\section{Future perspectives}

Present knowledge of the balance state of the ice sheet reveals that the ice margin is thinning rather rapidly in the southeastern and north-western parts of the ice sheet (Krabill et al. 1999). This is in contrast to earlier sensitivity estimates of ice sheet thinning during a warming climate (Huybrechts et al. 1991), that indicated the south-western and north-eastern marginal regions to react most strongly by thinning of the margin. Our present understanding of the climate sensitivity of the ice sheet margin is evidently insufficient. Surface observations are unfortunately lacking from several areas showing the most pronounced thinning in remote sensing data, including Melville Bugten in North-West Greenland and the ice margin south of Tasiilaq, East Greenland (Fig. 2).

Studies of the cryosphere (snow and ice on sea and land) have gained considerable focus in recent years, and new satellites have been developed specifically dedicated to monitor elevation changes from space. In 2003, NASA (National Aeronautics and Space Administration) launched the ICE-
SAT satellite, and in 2005 ESA (European Space Agency) will follow with the CRYOSAT satellite. However, the satellites only detect elevation changes and not the underlying causes. Additional in situ observations of climate and mass balance using AMS are needed for determining the annual mass balance 'turn-over' and detect possible changes. The new stations will be able to measure ice movement as well as ablation, although observations of elevation changes over several years will be required in order to derive long-term trends not biased by inter-annual fluctuations. Alternatively it may be possible to develop digital elevation models by making use of the Danish archives of aerial photographs dating back to about 1950. With the launch of new satellites and a more widespread use of AMS a detailed monitoring of the cryosphere becomes more realistic. Recently, a European Union programme (EuroClim) was initiated to develop a climate change monitoring system focusing on the cryosphere. One part of this system (under development at GEUS) aims at detecting changes in surface conditions of the Greenland Ice Sheet (Fig. 4). Furthermore, initiatives have been taken towards integrating land- and sea-ice studies to determine the climate sensitivity of the cryosphere and, not least, the impact of the cryosphere on the climate system. Both marine and terrestrial ice show similar interactions with climate. 


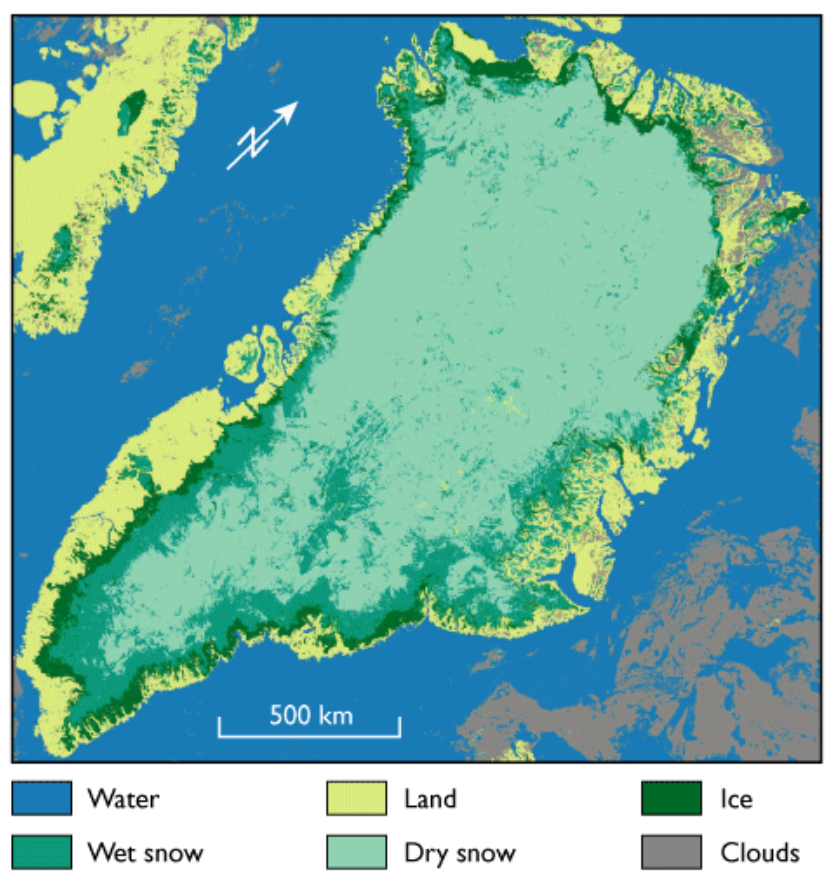

Fig. 4. Surface conditions over the Greenland Ice Sheet from MODIS imagery from August 2002, as part of the EuroClim Project. The surface is divided into several classes, ranging from pure ice at the ice sheet margin to dry snow in the interior. Calibration of the results requires confirmation by ground observations and high-resolution satellite data

\section{References}

Bamber, J.L., Layberry, R. \& Gogineni, S.P. 2001: A new ice thickness and bed data set for the Greenland Ice Sheet. Journal of Geophysical Research 106(D24), 33773-33780.

Beschel, R. 1961: Dating rock surfaces by lichen growth and its application to glaciology and physiography (lichenometry). In: Raasch, G. (ed.): Geology of the Arctic, 1044-1062. Toronto: University of Toronto Press.
Bøggild, C.E., Reeh, N. \& Oerter, H. 1994: Modelling ablation and massbalance sensitivity to climate change of Storstrømmen, Northeast Greenland. Global and Planetary Change 9, 79-90.

Bøggild, C.E., Olesen, O.B., Ahlstrøm, A.P. \& Jørgensen P. in press: Automatic glacier mass balance observations using pressure sensors. Journal of Glaciology.

Clark, P.U., Pisias, N.G., Stocker, T.F. \& Weaver, A.J. 2002: The role of the thermohaline circulation in abrupt climate change. Nature $\mathbf{4 1 5}$ 863-869.

Finsterwalder, R. 1959: Expédition Glaciologique Internationale au Groenland 1957-1960 (E.G.I.G.). Journal of Glaciology 3(26), 542-546.

Fischer, H., Wagenbach, D., Laternser, M. \& Haeberli, W. 1995: Glaciometeorological and isotopical studies along the EGIG-line, central Greenland. Journal of Glaciology 41(139), 515-527.

Huybrechts, P., Letreguilly, A. \& Reeh, N. 1991: The Greenland Ice Sheet and greenhouse warming. Global and Planetary Change 3(4), 399-412.

Krabill, W., Frederick, E., Manizade, S., Martin, C., Sonntag, J., Swift, R., Thomas, R., Wright, W. \& Yungel, J. 1999: Rapid thinning of parts of the southern Greenland Ice Sheet. Science 283, 1522-1524.

Linthout, K., Troelstra, S.R. \& Kuijpers, A. 2000: Provenance of coarse icerafted detritus near the SE Greenland margin. Netherlands Journal of Geosciences / Geologie en Mijnbouw 79(1), 109-121.

Mayer, C., Reeh, N., Jung-Rothenhäusler, F., Huybrechts, P. \& Oerter, H. 2000: The subglacial cavity and implied dynamics under Nioghalvfjerdsfjorden Glacier, NE-Greenland. Geophysical Research Letters 27(15), 2289-2292.

Mayer, C., Bøggild, C.E., Podlech, S., Olesen, O.B., Ahlstrøm, A.P. \& Krabill, W. 2002: Glaciological investigations on ice-sheet response in South Greenland. Geology of Greenland Survey Bulletin 191, 150-156.

Thomas, R.H. \& PARCA investigators 2001: Program for Arctic Regional Climate Assessment (PARCA): goals, key findings, and future directions. Journal of Geophysical Research 106(D24), 33691-33706.

Thomsen, H.H., Reeh, N., Olesen, O.B., Bøggild, C.E., Starzer, W., Weidick, A. \& Higgins, A.K. 1997: The Nioghalvfjerdsfjorden glacier project, North-East Greenland: a study of ice sheet response to climate change. Geology of Greenland Survey Bulletin 176, 95-103.

Weidick, A. 1995: Greenland. In: Williams, R.S.Jr. \& Ferrigno, J.G. (eds): Satellite image atlas of glaciers of the world. U.S. Geological Survey Professional Paper 1386-C, 141 pp.

\section{Authors' addresses}

C.E.B., C.M., S.P. \& S.N., Geological Survey of Denmark and Greenland, Øster Voldgade 10, DK-1350 Copenhagen K, Denmark. E-mail: ceb@geus.dk

A.T., Norwegian Polar Institute, Polarmiliøsenteret, N-9296 Tromsø, Norway. 